\title{
Arteria lusoria - a rare cause of dysphagia or a common accidental finding?
}

\author{
Martin Jozef Péča, Monika Kučeríkováb,c, Kristína Grilusováa, \\ Veronika Slobodníkováa, Alena Strýčkováb, Monika Beliančinovád, \\ Juraj Sokolb, Matej Samoša, Peter Galajdaa, Kamil Zeleňáke, Marián Mokáňa
}

a 1st Department of Internal Medicine, Jessenius Faculty of Medicine in Martin, Comenius University in Bratislava, Martin, Slovakia

${ }^{b}$ Department of Haematology and Transfusion Medicine, National Centre of Haemostasis and Thrombosis, Jessenius Faculty of Medicine in Martin, Comenius University in Bratislava, Martin, Slovakia

'Oncology Centre, University Hospital in Martin, Martin, Slovakia

${ }^{d}$ Department of Surgery and Transplant Centre, Jessenius Faculty of Medicine in Martin, Comenius University in Bratislava, Martin, Slovakia

e Clinic of Radiology, Jessenius Faculty of Medicine in Martin, Comenius University in Bratislava, Martin, Slovakia

\section{ARTICLE INFO}

Article history:

Submitted: 30.3 .2021

Revised: 6. 4. 2021

Accepted: 8. 4. 2021

Available online: 20. 9. 2021

Klúčové slová:

Artéria lusoria

Dysfágia

Kommerellov divertikul

Keywords:

Arteria lusoria

Dysphagia

Kommerell's diverticulum

\section{SÚHRN}

Najdôležitejšou abnormalitou aortálneho oblúka je bez diskusie prítomnost' artérie lusorie, aberantnej pravej artérie subclaviae. Práve prítomnost' tejto anatomickej štruktúry je často spätá s príznakmi spôsobenými útlakom jej okolia. Táto anomália sa zriedkavo spája aj s prítomnostou aneuryzmy v mieste jej odstupu z aortálneho oblúka - Kommerellovho divertikulu, ktorý nesie riziko ruptúry alebo disekcie. Prezentujeme vzácny prípad 84-ročnej pacientky s asymptomatickou aneuryzmou artérie lusorie, ktorá bolo diagnostikovaná náhodou počas hospitalizácie s následným endovaskulárnym ošetrením.

(C) 2021, ČKS.

\section{ABSTRACT}

The most important abnormality of the aortic arch is, without question, the presence of the arteria lusoria, the aberrant right subclavian artery (ARSA). The presence of this anatomical structure is often connected with symptoms caused by oppression in its surroundings. This anomaly is rarely associated with the presence of an aneurysm at the point of separation from the aortic arch - Kommerell's diverticulum, which carries the risk of rupture or dissection. We present a rare case of an 84-year-old patient with asymptomatic arteria lusoria aneurysm which was diagnosed by chance during hospitalization with subsequent endovascular treatment. Arteria lusoria and Kommerell's diverticulum were successfully endovascularly treated, resulting in good recovery.

\section{Introduction}

An obligatory abnormality of the aortic arch is the presence of the arteria lusoria ( $A L)$, which occurs in $0.7-2.0 \%$ population. ${ }^{1} \mathrm{AL}$ is the name for the aberrant right subclavian artery (ARSA), which comes out as the last branch of the aortic arch behind the left subclavian artery. In the presence of the ARSA the brachiocephalic trunk is missing, and four large arteries are emanating from the arch of the aorta (ARSA, right common carotid artery, left common carotid artery, left subclavian artery). This artery is passing in $80-84 \%$ of cases $^{2}$ through the posterior mediastinum, usually behind the oesophagus and often causes its compression. Dysphagia caused by $A L$ is called dysphagia lusoria. ${ }^{3}$ Rarely (12.7-15\%) AL is running between the oesophagus and trachea, thus compressing the airways and causes a prolonged cough. In $4.2-5 \%$ of patients, AL is pre-tracheal. ${ }^{3}$ Origin of the AL can also suppress the left recurrent laryngeal nerve and lead to the development of Ortner's syndrome. It is this symptomatology that leads to the patient being sent for examination in order to exclude the oncological process. Other symptoms may include retrosternal pain, weight loss, and claudication. ${ }^{4}$ In most cases $A L$ is asymptomatic and an accidental finding during autopsy, often associated with other aortic arch abnormalities. Kommerell's diverticulum (KD) is a very rare 
congenital anomaly and is characterized as aneurysmal dilatation of the ARSA at the beginning of its origin. ${ }^{5} \mathrm{KD}$ is associated with high risk of rupture or dissection. In this article we are presenting the case of a patient with $\mathrm{AL}$ and KD with an endovascular treatment.

\section{Case study}

The 84-year-old patient was admitted to our department for epigastric pain and hemodynamically insignificant enterorrhea. Her medical history included ischemic heart disease, type 2 diabetes mellitus, arterial hypertension, chronic kidney disease and medical records of dysphagia in previous examinations at the emergency department. Her recent medical treatment included a beta-blocker and sartan for the treatment of hypertension and oral antidiabetics for the treatment of type 2 diabetes mellitus. As a part of the initial examination, a chest radiograph was performed with the finding of suspected aneurysmal dilatation of the aorta or possibly another mediastinal lesion (Fig. 1). At the time of the admission to the hospital, her blood tests showed only moderate-grade normocytic anaemia. A colonoscopy examination was performed with the finding of severe diverticulosis from the anus to

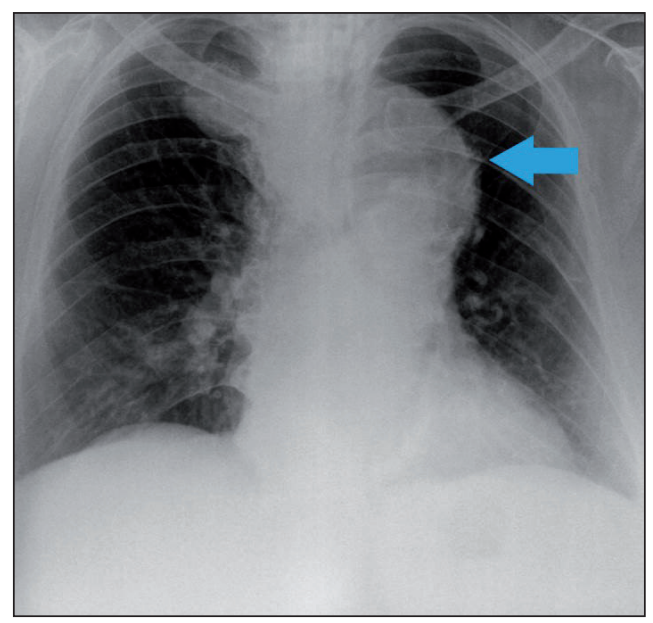

Fig. 1 - Chest radiograph with the finding of suspected aneurysmal dilatation of the aorta or possibly another mediastinal lesion.

lienal flexion, some diverticula were still actively bleeding during the examination, and this condition was assessed by surgeons as diverticulosis with a recommendation for conservative treatment without surgery and for hemosubstitution and hemostyptic treatment. For suspected aortic aneurysm, computed tomography (CT) thorax angiography was performed. The finding of the $C T$ angiography was aberrant right subclavian artery $(A L)$ with a fusiform aneurysmal extension present from the origin from the aortic arch with a maximum width of $55 \mathrm{~mm}$ and with the presence of a wall thrombus in the aneurysm extension (Fig. 2). AL was passing retroesophageal and deviated the oesophagus to the right. Vascular surgeons and radiologists recommended endovascular treatment of the thoracic aorta using a stent graft with an occlusion of ARSA distal to the aneurysm by occluders (Fig. 3). The proce-

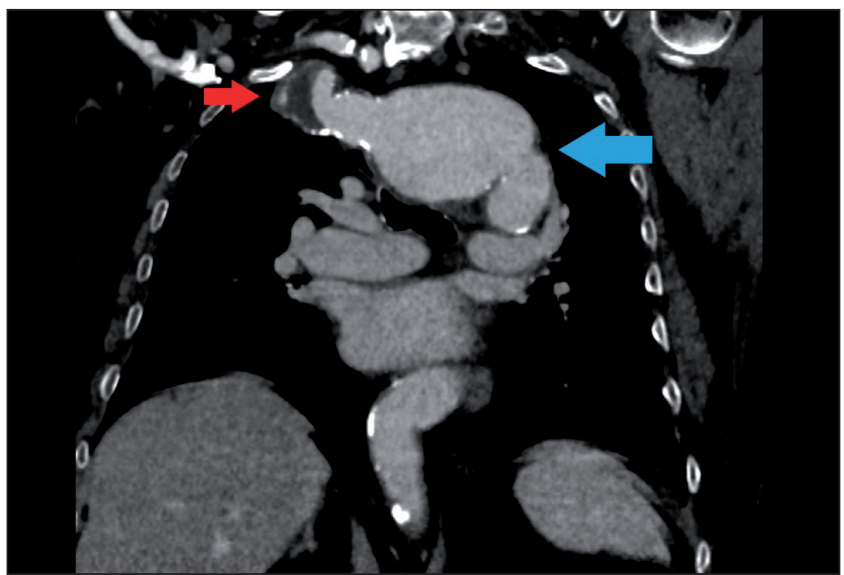

Fig. 2 - CT thorax angiography finds ARSA with a fusiform aneurysmal extension present from the origin from the aortic arch (Kommerell's diverticulum) with a maximum width of $55 \mathrm{~mm}$ and with the presence of a wall thrombus $(18 \mathrm{~mm})$ in the aneurysm extension.

dure was performed by interventional radiologists. After the intervention, the patient was set for anticoagulant treatment and she has been monitored regularly.

\section{Discussion}

AL was first described in the literature in 1735 by Hunauld, ${ }^{6}$ the word lusoria being formed from the Latin word lusus naturae, which means a trick of nature. AL is often dilated at the point of its separation and forms a diverticulum known as the Kommerell's diverticulum, first described by the German radiologist Burckhard F. Kommerell in $1936 .^{7}$ In the literature, the incidence of this diverticulum in $A L$ is described between 20 and $60 \%$. 3,6 Polguj et al. in his study of 141 cases showed the development of $A L$ is more common in women than in men and that $A L$ is symptomatic in only about $7-10 \%$ of cases. ${ }^{6}$ A higher presence of $A L$ is associated with genetic syndromes such as Down's and Edwards' syndrome. According to Nakajima et al. there is a higher incidence of $\mathrm{AL}$ even in Fallot tetralogy. ${ }^{8}$ Symptoms usually occur in two periods, in childhood and in

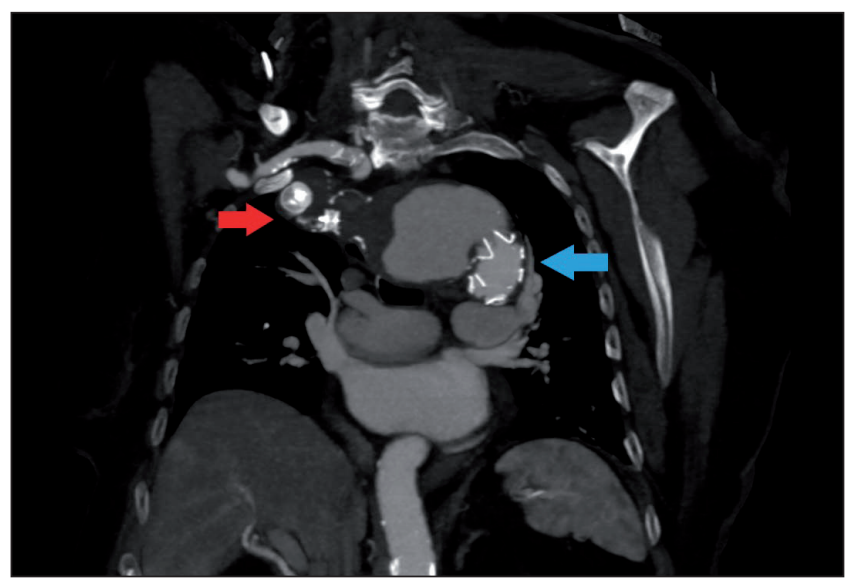

Fig. 3 - CT thorax angiography after endovascular procedure - treatment of the thoracic aorta using a stent graft combined with an occlusion of ARSA distal to the aneurysm by occluders. 
middle age. In children, the presence of AL usually manifests as cyanosis, stridor, and recurrent pneumonia due to underdeveloped trachea, which is easier to compress under AL pressure. In adults whose trachea is rigid and difficult to compress, this anomaly manifests as dysphagia. The mean age of patients diagnosed with symptomatic AL is 48 years. ${ }^{9}$ Diagnosis and differential diagnosis are based on imaging, radiographic findings, and thorax $\mathrm{CT}$. Treatment is indicated for the symptomatic relief of dysphagia and for the prevention of complications due to aneurysmal dilatation. There is no clear link between the size of the diverticulum and the need for surgery. The most common diverticulum complications include rupture, dissection, and thrombosis. ${ }^{5}$ Conventional surgical treatment and endovascular intervention are used to treat this anomaly, and the advantages and disadvantages of each option are constantly discussed. Currently, endovascular treatment is the preferred choice because it does not require central anaesthesia, is less invasive, takes less time and also has a lower risk of high blood loss..$^{10,11}$ However, endovascular treatment is only suitable for anatomical compatibility of AL with endovascular stent; otherwise the only option is open surgery. ${ }^{2}$ At present, advances in endovascular techniques have led to a hybrid alternative with combined open surgical and endovascular therapy. ${ }^{12,13}$ The presence of AL can cause undesirable complications in transradial coronary interventions. According to the literature, only $60 \%$ of the procedures during which the transradial approach was used, were successfully completed when AL was present. ${ }^{14}$ Sometimes during transradial approach a dissection of the ARSA may occur, so it is important to pay attention particularly to procedure, choose anatomically appropriate diagnostic catheters and specific manoeuvres and be prepared to prompt treatment if it is required. ${ }^{15}$

\section{Conclusion}

The arteria lusoria is a rare congenital anomaly of the aortic arch, which is also associated with other anomalies. It should not be forgotten that this aberrant right subclavian artery can cause difficulties mimicking other diseases, and therefore in the differential diagnosis of dyspnoea, dysphagia, retrosternal pain or weight loss, this rare diagnosis should be considered. It is especially important not to forget this unique diagnosis when distinguishing from other causes of dysphagia.

\section{Authors' contribution}

All authors contributed equally to preparing the manuscript.

\section{Conflict of interest}

The authors state that there are no conflicts of interest regarding the publication of this article.

\section{Funding body}

This work was supported by Slovak Research and Development Agency (APVV-17-0054), by research project of
Comenius University in Bratislava (UK/183/2021), and by Operational Programme Integrated Infrastructure ITMS 2014+: 313011V344.

\section{Ethical statement}

All procedures performed in studies involving human participants were in accordance with the ethical standards of the institutional review board and with the 1964 Helsinki declaration and its later amendments or comparable ethical standards.

\section{Informed consent}

Informed consent was obtained from the patient described in this report.

\section{References}

1. Tsukube T, Ataka K, Sakata M, et al. Surgical treatment of an aneurysm in the right aortic arch with aberrant left subclavian artery. Ann Thorac Surg 2001;71:1710-1711.

2. Coşkun E, Altınay L, Tekin A, Tütün U. Aberrant right subclavian artery (arteria lusoria) aneurysm with a Kommerell's diverticulum. J Vasc Bras 2019;18:e20180091.

3. Myers PO, Fasel JH, Kalangos A, Gailloud P. Arteria lusoria: developmental anatomy, clinical, radiological and surgical aspects. Ann Cardiol Angeiol 2010;59:147-154.

4. Tuleja A, Baumgartner I, Schindewolf M. Claudication Caused By Stenosis of Arteria Lusoria - Case Report and Review of Literature. Clin Med Insights Case Rep 2019;12:1179547619842187.

5. Tanaka A, Milner R, Ota T. Kommerell's diverticulum in the current era: a comprehensive review. Gen Thorac Cardiovasc Surg 2015;63:245-259.

6. Polguj M, Chrzanowski Ł, Kasprzak JD, et al. The aberrant right subclavian artery (arteria lusoria): the morphological and clinical aspects of one of the most important variations - a systematic study of 141 reports. ScientificWorldJournal 2014;2014:292734.

7. Kommerell B. Verlagerung des Osophagus durch eine abnormverlaufende Arteria subclavia dextra (Arteria Lusoria). Fortschritte auf dem Gebiete der Rontgenstrahlen 1936;54:590-595.

8. Nakajima Y, Nishibatake M, Ikeda K, et al. Abnormal development of fourth aortic arch derivatives in the pathogenesis of tetralogy of fallot. Pediatric Cardiology 1990;11:69-71.

9. Levitt B, Richter JE. Dysphagia lusoria: a comprehensive review. Dis Esophagus 2007;20:455-460.

10. Matsumori M, Kawashima M, Nomura $Y$, et al. Hybrid Repair of Kommerell's Diverticulum with Embolization of Aberrant Left Subclavian Artery. Ann Vasc Dis 2020;13:191-193.

11. Amore D, Casazza D, Casalino A, et al. Symptomatic Aberrant Right Subclavian Artery: Advantages of a Less Invasive Surgical Approach. Ann Thorac Cardiovasc Surg 2020;26:104107.

12. Sigdel A, Wayne EJ, Dwivedi AJ. Hybrid Endovascular Treatment of Dysphagia Lusoria: Report of 2 Cases. Vasc Endovascular Surg 2020;54:747-751.

13. Sabol F, Bilý B, Kolesár A, et al. Hybrid repair of aortic arch aneurysm. Cor Vasa 2014;56:e523-e526.

14. Valsecchi O, Vassileva A, Musumeci G, et al. Failure of transradial approach during coronary interventions: anatomic considerations. Catheter Cardiovasc Interv 2006;67:870-878.

15. Serra R, Rocca T, Traina L, et al. Arteria lusoria dissection with mediastinal hematoma as a complication of a transradial coronary catheterization: Case report and literature review. Int J Surg Case Rep 2020;75:426-428. 